\title{
1876 Yılında Edirne Vilayeti'ndeki Asayiş Problemleri (826 Numaralı Ayniyat Defteri Verilerine Göre)
}

\author{
Arzu Taşcan ${ }^{a, b}$
}

Özet

Anahtar Kelimeler

Ayniyat defterleri, XIX. yüzyılda Sadaret'ten taşra idarecilerine, nezaretlere ve diğer makamlara gönderilen yazıların aynen kaydedildiği defterlerdir. Defterlerde idari, mali, askeri, hukuki, sosyal ve farklı konular hakkında kayıtlar bulunmaktadır. Bu çalışmanın temel amacı 826 numaralı Ayniyat defterinde yer alan ve 1876 yılında Sadaret tarafından Edirne Vilayeti'ne gönderilen belgelere yansıyan olaylar ışığında asayiş problemlerini saptamaktır. Defterdeki belgeler Vilayete gönderilen kısa mektuplardan oluşmaktadır. Mektuplarda, halkın gönderdiği dilekçelerdeki şikâyet ve taleplerden bahsedilerek vilayet idarecilerine ne yapmaları gerektiği bildirilmiştir. Asayiş problemlerine dair defterden tespit edilen belgeler yağma, gasp, hırsızlık, cinayet, mala ve mahsule zarar verme, zorla zapt ederek başkasının mülkünün üzerine yerleşme, arazi ve mera çekişmeleri hakkındadır. 1876 ve öncesinde meydana gelen bu olaylarla ilgili halkın şikâyetleri karşısında vilayetteki yöneticilerin ve devletin nasıl bir davranış sergilediği defterdeki belgeler bağlamında irdelenmiştir. Edirne

\begin{tabular}{r} 
Edirne \\
Asayiş Problemleri \\
Arazi Müdahaleleri \\
Cinayet ve Hırsızlık \\
Makale Hakkında \\
\hline Geliş Tarihi: 03.06 .2020 \\
Kabul Tarihi: 26.03 .2021
\end{tabular}

Doi: 10.18026/cbayarsos.747612

\section{Public Order Problems in Edirne Province in 1876 According to Ayniyat Notebook Numbered 826}

\begin{abstract}
Ayniyat notebooks are the notebooks where the writings sent from Sadaret in the $\mathrm{XIX}^{\text {th }}$ century to the provincial administrators, ministries and other authorities were recorded exactly. There are registries about the administrative, financial, military, legal, social and other different matters in these notebooks. The main aim of this study is to determine public order problems which were reflected in the documents sent by Sadaret to the Edirne province in 1876 and are in the 826 numbered Ayniyat notebook. The documents in this notebook contain short letters sent to the province. In the letters, to the provincial administrators were informed about what they should do in front of complaints and requests of the public. The documents determined from the notebook on public order problems are about pillage, extortion, robbery, murder, damaging the crop and property, settling on someone else's property by force, land and pasture conflicts. The behavior of the administrators in provinces and state in the face of public complaints about these events that occurred in 1876 and earlier were scrutinized in the context of the documents in the notebook.
\end{abstract}

\section{Keywords \\ Edirne \\ Public order problems \\ Land interventions \\ Murder and theft \\ About Article \\ Received: 03.06.2020 \\ Accepted: 26.03.2021}

Doi: 10.18026/cbayarsos.747612

a İletişim Yazarı: arzu.tascan@cbu.edu.tr

b Dr. Öğr. Üyesi, Manisa Celal Bayar Üniversitesi Fen Edebiyat Fakültesi Tarih Bölümü, Osmanlı Müesseseleri ve Medeniyeti ABD, ORCID ID: 0000-0001-5618-8901. 


\section{Giriş}

1876 yılı Osmanlı Devleti'nin en buhranlı dönemlerinden biridir. Osmanlı Devleti mali, idari ve siyasi bakımdan bir kaos ortamı içerisindedir. Kırım Savaşı'ndan itibaren alınan dış borçlar ödenememiş, 1875 'te borç faizlerinin yarısının nakit ödeneceği kalan yarısının da senet ile ödeneceği ilan edilmiş, 1876 'da ise ödemeler durdurulmuştur (Pamuk, 2012, s. 2123; Küçük ve Ertüzün, 1994, s. 58-59). 1875 Haziran'ında başlayan Bosna İsyanı uluslararası bir mesele haline gelmiş, Zağra'da 16-21 Eylül 1875'te başarısızlıkla sonuçlanan bir isyana teşebbüs eden Bulgar komiteciler daha büyük bir ayaklanma hazırlığına başlamışlardır. Komitecilerin hazırlıklarına Osmanlı hükûmeti sessiz kalmış, Edirne valisi Akif Paşa'nın ikaz ve yardım taleplerini her defasında cevapsız bırakmıştır. Nitekim 2 Mayıs 1876'da başlayan ayaklanmayı Osmanlı Devleti ancak bir hafta sonra bastırabilmiştir (Aydın, 1992, s. 7-8). Bu ayaklanma devam ederken meydana gelen Selanik Vakası'nda Fransız konsolosu Moulin ve Alman konsolosu Abbot öldürülmüş, olay Avrupa basınında Müslüman-Hıristiyan çatışması olarak yer almış (Aydın, 2005, s. 39-40), yine aynı günlerde İstanbul'da medrese talebeleri ayaklanmış, bu hadise ile ilgili Rus elçisi tarafından "Müslümanlar silahlandılar, Hıristiyanları katledecekler" söylentisi yayılmış ve böylece art arda yaşanan hadiseler Avrupa politikasını Rusya'ya karşı Osmanlı taraftarlığından adım adım uzaklaştırmaya başlamıştır (Karal, 1988, s. 102-103). Mayıs ayındaki bu olayların etkileri sürerken Haziran ayının sonunda Sırbistan ve Karadağ savaş ilan etmiştir (Aydın, 1992, s. 9). Bütün iç ve dış sorunlara çözüm olarak, meşrûti rejim kurmak amacıyla bir saray darbesi gerçekleştirilmiş; Mayıs ayının sonunda Sultan Abdülaziz tahttan indirilmiş, yerine V. Murat ve ondan üç ay sonra da II. Abdülhamit tahta çıkarılmıştır. 1876 yılında Avrupa'nın büyük devletleriyle diplomatik bir mücadele içerisinde de olan Osmanlı Devleti, Balkanlardaki meseleleri görüşmek ve çözmek üzere Tersane Konferansı'nın toplandı̆̆ı gün Kanun-i Esasi'yi ilan etmiş, toplantı kararlarını ise hâkimiyet haklarını ihlal ettiği için kabul etmemiştir (Aydın, 1992, s. 9-10; Çetinsaya, 2016, s. 357).

Bu çalışmada Osmanlı'nın siyasi, idari ve mali alanlarda sıkıntılarının olduğu böyle bir kaos ortamında, dönemin en sıcak olaylarının yaşandığ 1 coğrafyada yer alan Edirne Vilayeti'nde meydana gelen asayiş problemlerine odaklanılmış, temel kaynak olarak da 826 nolu Ayniyat defterindeki belgeler kullanılmıştır. Ayniyat defterleri "XIX. yüzyılda Sadaret dairesinden nezaretlere, vilayetlere ve diğer makamlara yazllan tezkirelerin aynen suretlerinin kaydedildiği" (Aktaş, 1991, s. 277) defterlerdir. Osmanlı Arşivi'nde 595 nolu Bâb-1 Âli Evrak Odası Ayniyat Defterleri (BEO.AYN.d.) kataloğunda bulunan 1875 adet defter, Sadaret'in 1227-1330/18121912 tarihleri arasında bahsedilen makamlarla yapılan yazışmalarının muhtelif konulardaki kayıtlarını içermektedir (Başbakanlık Osmanlı Arşiv Rehberi, 2017, s. 119).

Söz konusu defterlerde; kamu davaları, şahsi davalar ve resmi makamlar arasındaki anlaşmazlıklar ile idari ve mali konuların yanı sıra nizamname ve talimatnameler yer almaktadır (Başbakanlık Osmanlı Arşiv Rehberi, 2017, s. 194). “Tanzimat sonrasında Şeriyye mahkemelerinin yetki alanından çıkarılan ve nizamiye mahkemelerine aktarılan dava konularına dair pek çok yazışmaya ayniyat defterlerinde tesadüf edilmektedir" (Gökmen, 2018, s. 444-445). Ayrıca "bu defterler sayesinde XIX. yüzyılda eyaletlerin durumu, Osmanl müesseselerinin ve bürokrasisinin işleyişi hakkında ayrıntılı bilgiler elde etmek mümkün olmaktadır"(Aktaş, 1991, s. 278).

"Ayniyat defterleri Osmanlı sosyo-ekonomik tarihi ile şehir tarihi çalışmalarında çok fazla kullanılmış defterler değildir" (Gökmen, 2018, s. 444) tespiti oldukça yerindedir. Bununla birlikte bu defterler müstakil olarak da çok fazla incelenmemiştir. Defterlerden sadece bir kaçı yüksek 
lisans tezi olarak çalışılmış ve sonuçlandırılmıştır. Çeşitli makalelerde ve kitaplarda bu defterlerde bulunan bazı belgelerden faydalanıldığı gibi, yalnızca Ayniyat defterlerinin ana kaynak olarak kullanıldığı kitaplar da yayınlanmıştır: 812, 829, 624 (624 nolu defter iki defa), 961 ve 928-926 numaralı Ayniyat defterleri yüksek lisans tezi olarak çalışılmıştır. Bunların yanı sıra 1 Nolu (Anadolu Adi) defter Ertan Gökmen tarafından incelenmiştir (Gökmen, 2018, s. 443-477). Yine Ertan Gökmen ve Ömür Yazıcı Özdemir tarafından 812 numaralı Aydın Ayniyat Defterindeki belgelere göre hazırlanan "Aydın Vilayeti'nde Suç ve Ceza (1866-1877)" (Gökmen ve Özdemir, 2016) ve 812 nolu defterle birlikte 813 nolu Aydın Ayniyat Defterinin de kullanıldığı "Ayniyat Defterleri Işığında Aydın Vilayeti'nin İdari, İktisadi ve Sosyal Durumu (1866-1880)" (Gökmen ve Özdemir, 2018) adlı kitaplar kayda değer çalışmalardır. Mehmet Çetin, Kırım Savaşı hakkında telif etmiş olduğu kitabında 300, 604, 723, 618 ve 724 numaralı Ayniyat defterlerindeki belgelerden faydalanmıştır (Çetin, 2016). Aynı yazarın Recep Kök ile birlikte yayınladığı diğer makalelerde de bu defterleri kullandığı görülmektedir. Ferhat Berber makalesinde 813 nolu Aydın Ayniyat defterinden istifade etmiştir (Berber, 2011, s. 17-49).

Osmanlı Arşivi'nde 595 nolu (BEO.AYN.d) kataloğunda 819-828 sıra numaralarında kayıtlı 10 adet "Edirne, Adana, Şarkî Rumeli" adlı defter bulunmaktadır (Başbakanlık Osmanlı Arşiv Rehberi, 2017, s. 120). Bu çalışmanın kaynağı olan 826 nolu "Edirne, Adana, Şarkî Rumeli" adlı defterdeki kayıtlar şukka (Kütükoğlu, 2018, s. 233; Pakalın, 2004, s. 360; Devellioğlu, 1993, s. 1003) adı verilen kısa mektuplardan oluşmaktadır.

Defterde, ilgili yıla ait Sadaret'ten Edirne Vilayeti'ne, sancak ve kazalara gönderilen toplam 194 adet belge bulunmaktadır. Bu şukkalar, vilayet dâhilinden bir mesele hakkında bilgi verilerek, halkın şikâyet ve taleplerini içeren dilekçeler vesilesiyle bilgilendirme, bilgi isteme ve çözüm amaçlı olarak gönderildiği gibi, bir talep olmaksızın da idari makamların bir konu hakkında bilgilendirilmesi, bilgi istenmesi veya bir işin yapılması, bir meselenin incelenmesi ve soruşturulması için Sadaret'ten gönderilmiştir.

1836 yılında yapılan bir düzenleme ile Rumeli Eyaleti'nin Paşa Sancağı'na bağlı bir kaza olan Edirne, "Edirne Eyaleti Müşirliğii" olarak yapılandırılmıştır (Çadırcı, 1987, s. 1227-1229; Karakuş, 2018, s. 200-203). 1864 Vilayet Nizamnamesi'nin ilan edilip uygulanmaya başlanmasına kadar geçen sürede taşra idaresinde 1840, 1842, 1846, 1849, 1852 ve 1858 yıllarında çeşitli düzenlemelere gidilmişse de Edirne'nin idaresinde çok fazla bir değişiklik olmamıştır (Efe, 2009, s. 87-109; Ünver, 2015, s. 98-100; Evci, 2019, s. 19-76). 1864 Vilayet Nizamnamesi başlangıçta pilot bölge olarak Tuna Vilayeti'nde, (Seyitdanlığlu, 2, 1996, s. 69), 1867 yılından itibaren Osmanlı coğrafyasının diğer bölgelerinde uygulanmaya başlamıştır (Seyitdanlıŏlu, 5, 1996, s. 89). Nizamname'ye göre oluşturulan Edirne Vilayeti'ne İslimye, Tekfurdağı, Gelibolu ve Filibe sancakları bağlanmıştır (Evci, 2019, s. 9495).

Defterdeki belgelerde vilayetin bu sancaklarının adı zikredilmektedir. Ancak sadece bir belgede Edirne' ye bağlı sancak olarak kaydedilen Sofya'nın (BEO.AYN.d. 826, No: 6429, 14 Ş 93/4 Eylül 1876, s. 193) 1877 yılının Edirne Vilayeti Salnamesi'nde sancak (Salname-i Vilayet-i Edirne, r. 1293/h. 1294/m. 1877, s, 103-112) olarak kayıtlı olduğu, incelenen dönem olan 1293/1876 yılının salnamesinde yer almadığı tespit edilmiştir (Salname-i Vilayet-i Edirne, h.1293/m. 1876). 1876 yılının salnamesine göre Edirne'nin sancak ve kazaları aşağıdaki tabloda gösterilmiştir (Salname-i Vilayet-i Edirne, h.1293/m. 1876, s. 47-88): 
Tablo 1. 1876 Yilında Edirne Vilayeti'nin Sancak ve Kazaları

\begin{tabular}{|l|l|l|l|l|l|}
\hline Sancaklar & Edirne & Filibe & İslimye & Gelibolu & Tekfurdağ1 \\
\hline \multirow{6}{*}{ Kazalar } & Dimetoka & Hasköy & Yanbolu & Keşan & Çorlu \\
& Cisr-i Mustafa Paşa & Zağra-i Atik & Misivri & Gümülcine & Hayrabolu \\
& Cisr-i Ergene & Kizanlı & Karinabad & Şarköy & Malkara \\
& Kirkkilise & Çı̈rpan & Aydos & İnöz & Vize \\
& Ferecik & Sultanyeri & Zağra-i Cedid & & Bergos \\
& Pinarhisar & Ahi Çelebi & Ahyolu Bergosu & & Midye \\
& Havsa & & & & Ereğli \\
& Kizılağaç & & & & \\
& Babay-1 Atik & & & & \\
& Edirne & & & & \\
\hline
\end{tabular}

Defterdeki belgelerde, idari birimlerin yanı sıra yöneticiler ve memurlar ile ilgili olarak atama, soruşturma, azl, idarecilerle halk arasında çeşitli konularda meydana gelen problemler hakkında bilgiler bulunmaktadır.

Belgeler, vilayetin iktisâdî ve bazı yönleriyle de sosyal hayatı hakkında veriler sağlamaktadır. Kayıtlardan, halkın ve hatta mültezimlerin vergilerden dolayı mağdur olduğu anlaşılmaktadır. Borç meseleleri ile istihdam ve maddi yardım talepleri diğer iktisadi ve sosyal konulardandır. Defterde askeri konularla ilgili vilayete gönderilen şukkalara rastlanmıştır. Bunların neredeyse tamamı ordu için toplanan yardımlar hakkındadır. Edirne Vilayeti'nde iskân edilen Kırım ve Kafkasya muhacirleri ve bunların yaşadıkları problemler defterdeki belgelerden tespit edilebilmektedir. Çerkeslerin karıştığı bazı saldırılardan, gasp ve araziye müdahalelerinden dolayı yapılan şikâyetlere bu makalede yer verilecektir. İdari, hukuki, sosyal, askeri ve iktisadi kategorileri dışında farklı konulara dair defterdeki diğer belgeler ise hizmetlerinden dolayı mükâfatlandırılma talepleri, İstanbul'a nakil izni, vilayet tarafına gidecek olanlarla ilgilenilmesi, tarım, ticaret ve inşaat işleri ile ilgilidir.

\section{Arazilere Yapılan Müdahaleler ve Mera Meseleleri}

\section{Arazilere Yapılan Müdahaleler}

Edirne Vilayeti'nde sahipli arazi ve mallara yapılan çeşitli saldırı ve müdahaleler bulunmaktadır. Müdahaleler, belgelerden anlaşıldığı kadarıyla iki şekilde meydana gelmiştir. Kişi veya gruplar bazen bir araziyi veya bir mülkü zapt ederek hem zarar vermişler, hem de kendi tasarruflarına alıp kullanmışlardır, bazen de sadece hırsızlık ve yağma amaçlı saldırılar gerçekleştirmişlerdir. Arazi, tarla ve çiftliklere yapılan saldırılarda ürün ve hayvanlar çalınırken, kalanların yok edilip telef olmasına sebebiyet verilmiştir. Arazilerine, can ve mallarına yapılan saldırıların ve müdahalelerin durdurulması, gerekli önlemlerin alınması, haklarının teslim edilmesi için mal sahipleri tarafından dilekçe ve telgraflar gönderilmiştir. Bunlarda bahsedilen problemler eğer mahalli idare tarafından soruşturulmuş ise konu ile ilgili elde edilen bilgiler bir mazbata halinde Sadaret'e gönderilmiştir. Bu mazbatalar Sadaret'te incelendikten sonra bir karara varıldiysa bu karar icra edilmesi için vilayete bildirilmiştir. Eğer bir karara varılamadıysa vilâyete hitaben gönderilen şukkalarda meselelerin içeriğinden bahsedilerek eğer olaylar doğru ise "devletin 
haksızlıklara rıza göstermeyeceği, halkın mal ve canını korumasının ve adaleti sağlamasının görevi olduğu" vurgulanmıştır. Daha sonra meselenin araştırılarak gereğinin yapılması ve sonucunun tekrar Sadaret'e bildirilmesi istenmiştir.

Kırkkilise Kazası'na bağlı İğneci Karyesi halkının vekili Hristo ve Ustoyan atalarından kalan tarla, mera ve mezrayı Edirneli Aleksan'ın zorla kiraladığını, oysaki ziraat zamanının geldiğini, 2000 lira harcayarak yaptıkları terasların bakımsız kaldığını anlatarak adalet istemişlerdir (No: 4955, 15 S 1293/12 Mart 1876, s. 146). Gelibolu Sancağı'na bağlı Şarköy Kasabası'nda çıkan yangına komşusu Dolaryus isimli kişinin sebep olduğunu, kendi arsasının bir tarafına ve mevcut enkaza da el koyduğunu anlatarak hakkını isteyen Atine tarafından dilekçe gönderilmiştir (No: 1383, 29 Ra 1293/24 Nisan 1876, s. 158). Yorgaki Zarifi ve Zafarvili efendiler Bergos Kazası'na bağlı Amedyazılı Karyesi'nin, (No: 433, 27 Ra 1293/22 Nisan 1876, s. 157); Tosun Bey ve adamları ise Derbend Karyesi'nin (No: 7248, 12 N 1293/1 Ekim 1876, s. 201) arazilerini zapt ederek arazi ve tarlalara zarar vermişler, köylüleri darp etmişler, azarlamışlar, büyük ve küçükbaş hayvanları telef etmişlerdir. Derbend'de 300 kadar kişi öldürülmüş, evler yakılmış, para ve eşyalar gasp edilmiştir. Vize Kazası'ndaki Ahi Mehmed Karyesi halkının vekili Bevanço tarafından gönderilen dilekçenin konusu ise köylünün arazilerine, ekinlerine ve binalarına Karabet tarafından verilen hasar ve bu konuda daha önceden vilayete bildirilmiş olan hükmün icrası hakkındadır. Belgeden, Sadaret tarafından 8 Haziran 1875 tarihinde bu mesele hakkında araştırma yapılarak gereğinin hemen yerine getirilmesinin ardından sonucunun da bildirilmesinin istendiği, ancak vilayetten henüz cevap verilmediği anlaşılmaktadır (No: 10602, 16 M 1293/12 Şubat 1876, s. 137). Bir süre sonra Karabet tarafından yapılan saldırı ve tecavüzlerin durdurulması talebiyle bir dilekçenin daha gelmesi üzerine vilayete gönderilen bir önceki hüküm tekrarlanmıştır. (No: 446, 21 Ra 1293/16 Nisan 1876, s. 156). Ahi Mehmet Karyesi hakkındaki belgelerdeki verilere göre Karabet adlı şahıs önceki yıllardan itibaren aynı bölgeye saldırılar gerçekleştirmiş, halk da haksızlıklardan korunmaları için bölgedeki idarecilerden yardım istemiştir. Ancak meselenin henüz halledilemediği anlaşılmakta, asayişi sağlama noktasında taşradaki en üst sorumlu merci olan valiliğin bir yıl önce gönderilen mektubu cevapsız bırakmış olması mesele hakkında herhangi bir girişimde bulunulmadığını düşündürmektedir.

Yukarıdaki hadiselerin gayr-i Müslimler tarafından yine gayr-i Müslimlere yönelik olarak gerçekleştiği görülmektedir. Belgelerdeki verilere göre, yapılan saldırıların siyasi veya mezhepsel/dinsel bir durumdan kaynaklanmadığı söylenebilir. Yalnızca bir olayda zarar veren taraf Müslim, şikâyetçi taraf da gayr-i Müslim'dir. Gerek gayr-i Müslimlerin kendi aralarında, gerekse aşağıda bahsedilecek olan Müslimlerin kendi aralarındaki meselelerde "olayların araştırılması ve adaletin sağlanması" için merkezden memur tayin edilmediği gibi takviye kuvvet gönderilebileceğine dair diğer belgelerde bir bulguya rastlanmamıştır. Ancak aşağıdaki belgede anlatılan olayda Müslimlerin gayr-i Müslim bölgelerine saldırıları söz konusudur ve meselenin araştırılıp çözüme kavuşturulması için memur görevlendirilmiştir. Ayrıca gerekirse askeri kuvvet desteğinin sağlanabileceği de vilayete beyan edilmiştir:

Hem İslimye Mutasarrıflığı'na, hem de Bergos Kaymakamlığı'na gönderilen şukkada tüccar Mösyö Zarifi'nin dilekçesinin içeriğinden bahsedilerek yetkililer tarafından olayların önlenmesi için bir girişimde bulunulmadığı belirtilmiştir: Mösyö Zarifi'nin Bergos Kazası'nda bulunan çiftliğine, civardaki diğer çiftlik ve köylere Çerkeslerden bazı şahıslar musallat olmuş, hayvanları gasp ve yağma etmiş, mahsulleri çalmışlardır. Gönderilen 
şukkadaki bu açıklamadan sonra meselenin araştırılması için Zühdü Bey'in görevlendirildiği, çalışmaları esnasında kendisine gerekli kolaylığın sağlanması, ayrıca çalınmış olan hayvanlar ve diğer şeylerin buldurulup sahiplerine teslim edilmesi, çalanların yakalanıp hapsedilmesi, eğer mevcut kolluk güçleri yetersiz ise yeteri kadar askerin geçici olarak bu meselede görevlendirilmesi için gereğinin yapılması vilayete tebliğ edilmiştir (22 Ca 1293/15 Haziran 1876, s. 172).

Aşağıdaki olaylarda hem saldırıda bulunan hem de saldırıya uğrayan kesim Müslüman'dır. Bunlardan ilki hariç diğer dört olayda Çerkeslerin dahli söz konusudur. Olaylarda yerli halkın Çerkeslerden, Çerkeslerin de yerli halktan araziye müdahale, mülkü zapt ederek yerleşme, hırsızlık, mala ve mahsule zarar verme gibi konularda şikâyetlerinin olduğu görülmüştür:

Müderris Ahmed Faiz Efendi Kırkkilise Kazası'na bağlı Koçlu Karyesi sınırındaki Tokmakoğlu isimli mevkide bulunan ve 22 seneden beri oğlunun olan araziye diktikleri 80.000 kuruş kıymetindeki bağın Hacı Mehmed ve Benlioğlu Ali tarafından memur getirilerek bostanlarıyla beraber koparılıp telef ettirildiğinden bahsederek meydana gelen hasarın ödenmesini talep etmiştir (No: 608, 14 M 1293/10 Şubat 1876, s. 136). Ahyolu Bergosu Kazası'ndaki Ruskasrı Karyesi'nin eski muhtarı tarla ve çayırlarının bir senedir bazı Çerkesler tarafından zabt edildiğini, bu nedenle perişan olduklarını anlatmıştır (No: 117, 3 Ra 1293/29 Mart 1876, s. 155). Ahmed Ağa tarafından yapılan şikâyetin konusu da yukarıdaki ile aynıdır. Ahmed Ağa'nın Çorlu Kazası'nda bulunan Hacı Şeremet adlı çiftlik arazisine Alefli Karyesi'nde ikamet eden Çerkesler zarar vermiştir. Belgedeki, Sadaret'in 7 Aralık 1875 tarihli yazısıyla vilayetten meselenin çözüme kavuşturulmasının istendiği bilgisinden (19 Za 1293/6 Aralık 1876, s. 214) Ahmed Ağa'nın daha önceden de aynı şikâyetlerle dilekçe gönderdiği, yukarıda bahsedilen Ahi Mehmed Karyesi'nde olduğu gibi, vilayetteki yöneticilerin bu meseleyi çözmek için girişimde bulunmadığı anlaşılmaktadır.

Mağdur olduklarını iddia eden Çerkesler de gönderdikleri dilekçelerle haklarını aramışlardır. Gelibolu Sancağı'nda Koyuntepe Nahiyesi'ne iskân edilmiş Çerkes göçmenlerden Osman Bey, Sarı Balabancık'ta yerleştirilmiş olan muhacirlerden 10 hane halkının, hanelerini satıp Koyuntepe Nahiyesi'ne gelerek 60 liralık hayvanını çaldıklarından ve epeyce erzakını yaktıklarından, bununla beraber civardaki diğer muhacirlerin de arazisini zapt ederek çiftçilik yaptıklarından bahsetmiş, bu müdahalelerin durdurulmasını istemiştir (No: 1469, 8 R 1293/3 Mayıs 1876, s. 159). Çerkeslerden Sefer Paşazâde İbrahim Paşa Cisr-i Ergene Kazası'nda Çatalkırı merası civarındaki arazisine tüccar Hasan Ağa'nın koyunlarını salarak zarar verdiğini ve çıan çatışmada çalışanlarından birisinin vurularak öldürüldüğünü anlatmış, katillerinin bulunarak cezalandırılması isteğiyle şikâyette bulunmuştur (No: 1512, 14 Ca 1293/7 Haziran 1876, s. 167).

\section{Mera Meseleleri}

Osmanlı Devleti 1274/1858 tarihli Arazi Kanunnamesi ile "devletin aslî üretim aracı ve vergi kaynă̆ı olan toprağın kullanımı, tasarrufu ve işletilmesini belirli esaslara bağlamıştır" (Kenanoğlu, 2006, s. 134). Kanunnamede arazi beş kısıma ayrılmıştır (Tanzimat Sonrası Arazi ve Tapu, 2014, s. 12-18; Günay, 2004, s. 416). Bunlardan arazi-i metrûke iki kısım halinde düzenlenmiştir: (Beşinci madde) "Arazi-i metrûke iki kısımdır. Biri umum nâs için terk olunmuş olan yerlerdir ki tarîk-i âmm bu kabîldendir. Diğeri bir karye ve kasaba veya kurâ ve kasabât-ı mütéaddidenin umum ahalisine terk ve tahsis olunan yerlerdir ki ahali-i kurâ ve kasabâta tahsis 
kılınmış olan meralar bu kabîldendir" (Tanzimat Sonrası Arazi ve Tapu, 2014, s. 104-105). Maddenin ikinci kısmında bahsedilen meralar belli bir veya birkaç köy ya da kasaba halkının kullanımına terk ve tahsis edilmiş yerlerdir. Metruk terimi de bu yerlerin terk ile sahipsizleştirilmesini değil, aksine halkın istifadesine tahsis edilmiş olduklarını gösterir (Cin, 1980, s. 30). Kanunnamenin 97-100. maddeleri de doğrudan mera ile ilgili maddelerdir (Tanzimat Sonrası Arazi ve Tapu, 2014, s. 122-123; Cin, 1980, s. 36-37).

Arazi meselelerinden olan meraların, statülerinden dolayı ayrıca değerlendirilmesi gerekmektedir. Çünkü meralar özel mülk olmayıp kamu malından sayılmaktaydı ve 1858 tarihli Arazi Kanunnamesi'ne göre meralardan ancak kanunen istifade hakkı olan bir veya birkaç köy ortaklaşa faydalanabilirdi (Cin, 1980, s. 6-7; 36-37). "Mera, yaylak, kışlak, çayır, otlak gibi köy orta malları insanların toplu yararlandikları yerler olduğundan toplum yaşantısında önemli bir yere sahiptir. Bu malların kullanımında ortaya çıkan anlaşmazlıklar bütün köy veya belde halkın ayaklandırabilmekte, silahlı çatışmalara yol açabilmektedir... Hak sahibi olmayanların oradan yararlanmaya kalkışması çekişmeler doğurmakta ve bu çekişmeler bütün bölge halkına yayılabilmektedir" (Çeken, 2018, s. 861).

Ayniyat defterinde mera çekişmeleri ile ilgili altı adet belge tespit edilmiştir. Olaylar Kırkkilise, Ahyolu, Edirne ve Tekfurdağı'nda meydana gelmiştir. Her ne kadar bu konu hakkında Sadaret'ten yazılan şukkalarda açı bir hüküm bulunmasa da "yapılacak araştırmanın sonucunda" 1858 tarihli Arazi Kanunnamesi'ndeki meralara ilişkin maddelere göre karar verileceğini, yani Kanûnnâmenin uygulanmakta olduğunu ifade etmek yanlış olmayacaktır. Aşağıdaki ilk belgeye göre Kırkkilise Kasabası'nın halkının taleplerinde haklı oldukları yapılan araştırmalar ile anlaşılmıştır. Arazi Kanunnamesi'nin beşinci maddesine göre de "bir yerin mera sayılabilmesi için bu amaçla bir köy veya kasabaya tahsis edilmiş olması gerekir. Bir tahsis bulunmadığı takdirde kadimden beri o yerin mera olarak kullanılagelmiş olması gerekir" (Cin, 1980: 36; Tanzimat Sonrası Arazi ve Tapu, 2014, s. 104-105).

Ahali vekilleri tarafından gönderilen telgrafta anlatılanlara göre Kırkkilise Kasabası civarında olup 30-40 seneden beri bağ haline getirilen Uğurlu Şeyh ve Tokçaoğlu çalılığ1 isimli mezralara bazı kişiler tarafından otlak/mera denilerek müdahale edilmiştir. Sadaret bu meseleyi Defter-i Hakani Nezareti'ne havale etmiştir. Nezaret'ten alınan cevapta Uğurlu Şeyh mezrasının Kırkkilise Kazası'na bağlı Hass-ı Hümayun dâhilindeki mîri araziden olup bazı kişilere tapu senetlerinin verildiği ve Tokçaoğlu mezrası hakkında da bilgi olmadığı belirtilmiştir. Ayrıca kanuna göre ahalinin senetlerinde belirlenmiş olan sınır dâhilindeki mahallerin eskisi gibi üzerlerinde kalması, senetleri olmayanların tasarruflarının araştırılarak "usul ve nizamınca" senet verilmesi gerektiğinin 30 Ocak 1875 tarihinde Edirne Vilayeti'ne bildirildiği anlaşılmıştır. Ancak müdahalelerin devam etmesi ve ürünlerin telef edilmesi üzerine meydana gelen zarar ve ziyanlarının tazmin edilmesi hakkında tekrar dilekçe gönderilmiş, bunun üzerine vilayete yazılan şukkada 30 Ocak 1875 tarihindeki hüküm tekrarlanmıştır (No: 10830, Gurre-i S 1293/26 Şubat 1876, s. 140).

Aşağıdaki olaylarda bahsedilen meselelerin Kanunname'nin doksan yedinci maddesi ile ilgili olduğu anlaşılmaktadır; "mera, hangi köy veya kasabaya tahsis edilmiş veya hangi köy veya kasaba kadimden beri o yeri mera olarak kullanıyorsa, ancak o köy veya kasabaların ahalisi meradan istifade edebilirler; başkalarının meradan faydalanma hakkı yoktur. Mera olarak tahsis edilmiş olan veya kadimden beri mera olarak kullanılagelen yerler alınıp satılamaz" (Cin, 1980, s. 36; Tanzimat Sonrası Arazi ve Tapu, 2014, s. 122). Belgeler bir köyün hayvanlarının otlaması için tahsis edilen meralara yapılan müdahalelerin durdurulması hakkındadır. Ahyolu Kazası'ndaki 
meselenin konusu mera arazisinin tarla haline getirilerek satılmasına teşebbüs edilmesi, Ada Nahiyesi'ndeki ise bir köy halkının başka bir köyün tasarrufuna bırakılan merayı zapt etmesidir:

Ahyolu Kazası halkı Soka isimli meranın bazı kişiler tarafından tarla haline getirilmesi üzerine mahalli idareye başvurmuş ise de Deâvi Meclisi'nden düzenlenen mazbata ile "arazi-i mektûme" denilerek burasının satılmasına teşebbüs edilmiştir. Ahali, meranın kendi hayvanlarının otlamasına tahsis edildiğinin ellerinde bulunan eski bir hüccette "yazılı ve kayıtlı" olup, eğer mühendis gönderilip keşif yaptırılırsa gerçeğin ortaya çıkacağını, iddialarını ispatlayacaklarını ifade etmiş, tarlanın tekrar eski durumuna getirilmesini istemişlerdir (6 S 1293/3 Mart 1876, s. 143). Edirne Vilayeti'nde bulunan Ada Nahiyesi'ne bağlı Ahır Karyesi halkına ait olan meranın bazı bölgeleri Bosna Karyesi halkı tarafından zapt edilmiştir. İki tarafın mahkeme edilerek bu zaptın durdurulması gerektiği vilayete bildirilmiştir (No: 8742, 11 Za 1293/28 Kasım 1876, s. 211).

Kara Halil Karyesi'nde meydana gelen mera hakkındaki ihtilaf ile ilgili üç adet belge mevcuttur. Aynı mesele hakkındaki belgelerin çokluğu meselenin çözüme kavuşturulması için vilayet idaresi tarafından bir girişimde bulunulmadığının da delilidir. İhtilafın sebebi ve meselenin ne şekilde cereyan ettiği belgede açıkça belirtilmemekle beraber şikâyetçi olan tarafın Kara Halil Karyesi'nin halkı olduğu göz önünde bulundurulduğunda iki ayrı tahmin yürütülebilir: Abdi Bey çiftliğini genişletmek amacıyla merayı ziraate açmaya teşebbüs etmiştir veya meradan istifade hakkı olmadı̆̆ı halde hayvanlarını meraya salmıştır. Köylünün şikâyeti doğru ise Abdi Bey, tahmin edilen müdahalesinde Arazi Kanunnamesi'nin ilgili maddesine göre haklı değildir. Doksan yedinci maddede bu husus oldukça açık ifade edilmiştir: “...mera sınırları daraltılıp genişletilemez ve meraların vasfı değiştirilemez..." (Cin, 1980: 37; Tanzimat Sonrası Arazi ve Tapu, 2014, s. 122).

Tekfurdağı Sancağı'ndaki Kara Halil Karyesi'nde bulunan çiftliğin sahibi olan Hacı Abdi Bey ile köy halkı arasındaki mera çekişmesinin mahallince halledilmesi hakkında daha önceki emr-i âli hükmüne Abdi Bey tarafından bazı sıradan sebeplerle engel olunmaktadır. Abdi Bey'in tutumları mağduriyetlere yol açtığı için emr-i âli hükmünün hemen yerine getirilmesi, kendilerinin haksızlıktan korunması isteğine dair köylülerin vekili Ahmed tarafından dilekçe gönderilmiştir. Meselenin sebepsiz yere ertelenmesinden dolayı köylüler sıkıntıya uğramışlar ise, bu durum "gayr-i câiz" bulunmuştur. Bu mesele hakkında 21 Şubat 1875 tarihinde çıkarılan emr-i âliye uygun olarak iki tarafın mahkemelerinin yapılması, mahkeme sonucuna göre gereğinin yerine getirilmesi ve sonucun Sadaret'e beyan edilmesi vilayete bildirilmiştir (20 M 1293/16 Şubat 1876, s. 139). Daha sonra Ahmed imzasıyla bir dilekçe daha gönderilince vilayete yine aynı ifadelerin tekrarlandığ ${ }_{1}$ bir emr-i âli daha gönderilmiştir. Bunda ise meselenin sona erdirilmesi için gereğinin yapılmasının 16 Şubat 1876 tarihinde bildirildiği ancak cevap alınamadığı hatırlatılmıştır (No: 2884, 9 C 1293/2 Temmuz 1876, s. 177). Bütün bu uyarılara rağmen meselenin hala sonuçlandırılmadı̆̆ı Ahmed'in tekrar dilekçe göndermesinden anlaşılmaktadır. Üçüncü defa vilayete gönderilen emr-i âlide, bu defa da bir öncekinin tarihi belirtilmiş (2 Temmuz 1876), meselenin henüz çözülmediğinin tespit edildiği ifade edilmiş, adaletin bir an önce yerine getirilmesi ve sonucun bildirilmesi yinelenmiştir (3 Z 1293/20 Aralık 1876, s. 215). 


\section{Arazi Hakkındaki Diğer Meseleler}

Defterde, yine arazi ile ilgili olup ancak yukarıdaki kategorilere dâhil edilmeyen kayıtlar bulunmaktadır. Bunların dördünde de dilekçe gönderen kişiler başlarına gelen olayı anlatmış ve mağdur olduklarını beyan ederek adalet talebinde bulunmuşlardır.

17 Mart 1876 ve 21 Aralık 1876 tarihlerinde Edirne Vilayeti'ne gönderilen şukkalarda Merhum Aliş Paşa'nın karısı Şerife Azime Hanım'ın geçim sıkıntısında olduğu anlaşılan dilekçeleri özetlenmiştir. Şerife Hanım ilk dilekçesinde Üsküdar Nahiyesi'ndeki İsmailice çiftliğinin arazisinde bulunan ve üç sene öncesine kadar 1000 kuruşa kiraladığı tarla ve çayırın başkalarına kiralanmasının mağdurluğuna sebep olduğundan bahsetmekte, buraların eskiden olduğu gibi kendisine bırakılmasını talep etmektedir. Bu ilk belgedeki, 20 Ocak 1876 tarihli aynı konudaki bir yazının vilayete gönderilmiş olduğu bilgisinden hareketle Şerife Hanım'ın bu husustaki ilk dilekçesini Ocak 1876'dan önceki tarihlerde gönderdiği söylenebilir (20 S 1293/17 Mart 1876, s. 150). Diğer bir dilekçesinde Şerife Hanım, vefat eden oğlundan kalma borca karşılık İsmailice çiftliğinin bazı kişilerce satılmasına teşebbüs edildiğinden bahsederek borcunun gelecek hasat zamanına ertelenmesinin sağlanmasını ve ancak o zaman tamamen ödeyebileceğini ifade etmiştir (No: 9174, 4 Z 1293/21 Aralık 1876, s. 216).

Hariciye Teşrifatçısı Kâmil Bey Keşan Kazası'ndaki çiftlik arazisinin ürünlerini yarı yarıya bölüşmek üzere Korucu Karyesi'nin halkı ile anlaşmış, ancak köylünün arazilerindeki ürünlerin de yarısını almak için mahallinden bir ilam elde etmiştir. Zor durumda kalan köy halkı haklarının korunmasını istemiştir (No: 000, 7 N 1293/26 Eylül 1876, s. 200). Ahyolu Bergosu Kazası'ndan Süleyman, Evkaf-ı Hümâyûn Hazinesi'nden 20 sene önce tefevvüz etmiş olduğu çiftlik ve sairenin, kaptan-ı derya merhum Halil Rıfat Paşa'nın aile arazisinin araştırılması amacıyla görevlendirilen Fuad Bey tarafından mahlûl addedilerek satışına teşebbüs edildiğini haber vermekte ve hakkının korunmasını istemektedir (No: 1526, $9 \mathrm{C}$ 1293/2 Temmuz 1876, s. 176).

\section{Hırsızlığa Dair Kayıtlar}

Hırsızlığa dair belgelerde yukarıdakiler gibi sadece olaydan bahsedilmektedir. Defterde hırsızlığa dair üç vakanın kaydı bulunmaktadır. Bunlardan biri kırsal kesimde, diğerleri daha merkezi yerlerde meydana gelmiştir.

22 Temmuz 1873'te Edirne Hükümet Konağg'nın içindeki postaneden 20.000 kuruşun çalınmasına posta memuru Hacı Mustafa ile postacı Emin Efendi isminde iki kişinin dâhil olduğu yapılan tahkikatta anlaşılmıştır. Bu kişiler hakkında daha ayrıntılı soruşturma yapılarak çalınan tutarın ve hırsızların mutlaka ortaya çıkarılması 2 Ocak 1874 tarihinde Edirne Vilayeti'ne bildirilmiştir. Ancak o zamandan beri bir cevap alınamadığ Nezareti meselenin vilayete tekrar tebliğ edilmesini talep etmiştir. Bunun üzerine Sadaret tarafından vilayete gönderilen şukkada yukarıdaki bilgiler verilmiş ve vilayet makamına ne yapılması gerektiği bildirilmiştir: “...fezâyiha cür'et idenlerin cezâsız bırakılması câ'iz olmadiğı gibi ahz iyledikleri akçenin sâhiblerine te'diye ve tazmîn idilmiş olmasından dolayı Hazîne-i Mîri'ye bâr ve hasar idilmesi dahi gayr-ı lâyı bulunmuş olduğundan ve husûs-ı mezkûrun böyle müddet-i medîde te'hîr idilmesi sebebi bilinemediğinden keyfiyetin bi'l-etrâf tahkîk ve tetkîkiyle hâsıl olacak netâyicin beyân ve tenmîkine himmet buyrulması..." (No: 7, 28 R 1293/23 Mayıs 1876, s. 162). 
Bu konu hakkındaki diğer iki belge hırsızlık nedeniyle uğradıkların zararların karşılanması amacıyla Çerkeslerin gönderdikleri dilekçeler hakkındadır. Hacı İshak, Sofya' da ikamet eden biraderi Hamza Efendi'nin Edirne'de istasyon civarında gecelemiş olduğu han odasından çalınmış olan eşyasının bulunmasını (No: 1797, 10 R 1293/5 Mayıs 1876, s. 159); Kızılağaç Kazası Duraklı Karyesi'ndeki muhacirlerden birkaç kişi ise kölelerinin cariye, eşya ve hayvanlarını alarak kaçtıklarını beyan ederek adaletin yerine getirilmesini istemişlerdir (No: 635, 14 R 1293/9 Mayıs 1876, s. 160).

\section{Cinayet ve Cinayete Teşebbüse Dair Kayıtlar}

$\mathrm{Bu}$ konu hakkındaki olaylardan ikisi cinayete teşebbüs edilmesi hakkındadır. Çerkes muhacirlerinden Fatma Hanım'ın meselesi Zabtiye Nezareti'ne ve buradan da Muhacirîn İdaresi'ne havale edilmiştir. Çünkü Osmanlı Devleti'nde muhacir işleri ile ilgilenmek üzere 5 Ocak 1860'ta kurulan Muhacir Komisyonu 10 Mart 1875'te lağv edilince muhacir işleri Zaptiye Nezâreti'ne bağlı bir Muhacirîn İdaresi tarafından idare edilmeye başlamıştır (İpek, 1994, s. 68-69; Erdem, 2018, s. 75-77; Saydam, 2016, s. 288-290; Taşkesenlioğlu, 2015, s. 560).

İslimye Sancağ $\breve{1}$ Meclis-i Temyiz üyelerinden Arif Efendi'nin cinayet işlemeye teşebbüs ettiği ihbar edilince vilayetten meseleyi etraflıca araştırması için bir memur görevlendirmesi istenmiştir (No: 4365, 12 M 1293/8 Şubat 1876, s. 136). Yine İslimye Sancağ1 Bergos Kazası Ayvacık Karyesi'nde iskân edilen Çerkes muhacirlerinden Fatma Hanım, bazı kişilerin Hasan adlı birisini azmettirerek kocası Ahmed'i öldürtmeye çalışmasından bahsedip güvenliklerinin sağlanması talebiyle dilekçe göndermiştir. Sadaret tarafından bu mesele Zaptiye Nezâreti'ne havale edilmiş ve oradan bilgi ve karar beklenmiştir. Nezaret de ilgili olan daireye, yani Muhacirîn İdaresi'ne durumu bildirmiştir. Yine sırasıyla Muhacirîn İdaresi'nin Zaptiye Nezareti'ne tebliği Sadaret'e beyan edilmiştir. Buna göre vilayete gönderilen şukkada merkezdeki yazışmaların bütün bu aşamaları anlatılmış, ardından olayın tetkik edilmesi, şikâyet edilen husus doğru ise gerekenin yapılması istenmiştir (No: 11637, 23 S 1293/20 Mart 1876, s. 151).

Aşağıda anlatılan iki olay ise darp nedeniyle ölüm hadisesinin meydana gelmesi hakkındadır. İlk olayda katillerin yerlerinin tespit edilemediği anlaşılmaktadır. İkinci olayda ise cinayet zanlısı olarak tutuklanan kişinin suçsuzluğu iddia edilmektedir.

Pazarcık'ta İbrahim Bey'i yaralayarak ölmesine sebep olan Ganto ve kardeşi Ustoyan'ın kaçarak İstanbul'a gittikleri Edirne Vilayeti'nden Sadaret'e ihbar edilmiştir. Bu ihbar üzerine Zabtiye Nezâreti tarafından araştırma yapıldığı, ancak bu kardeşlerin bulunamadıkları gibi İstanbul'a geldiklerine dair bir ipucu ve bilginin saptanamadığı, araştırılmaya devam edildiği, eğer bulunurlarsa hemen mahalline yollanacakları, ayrıca mahallince de araştırmaların sürdürülmesi vilayete bildirilmiştir (No: 917, 23 M 1293/19 Şubat 1876, s. 140). Filibe Sancağı'na bağlı Tatarpazarı Kasabası'ndan bazı kişiler Nedim isimli kişinin darp sonucu ölen Nikola'nın katlinden dolayı tutuklandığını, ancak kendisinin cinayet ile alakasının olmadığını iddia ettikleri bir dilekçe göndermişlerdir (No:11139, 2 S 1293/28 Şubat 1876, s. 142).

Arazi meseleleri bahsinde de yer verilmiş olan aşağıdaki belgenin "cevâbnâmesi" bulunmaktadır. Çerkes muhacirlerinden Sefer Paşazâde İbrahim Paşa, Cisr-i Ergene Kazası Çatalkırı merası civarındaki arazisine tüccar Hasan Ağa'nın koyunlarını salarak zarar 
verdiğini, bunu önlemek isteyen Mahmud adlı çalışanını ise vurarak öldürüp kaçtığını, sonradan kazaya gelerek olaydan haberi olmadığını beyan ettiğini, bu sırada gözaltına alındığını ve ifadesini değiştirerek serbest kalmaya çalıştığını bildirmiş, Hasan A Ăa ile çobanlarının yakalanıp yargılanmalarını talep etmiştir. Bunun üzerine vilayete gönderilen şukkada cinayet işleyenlerin yakalanıp yargılanmaları ve cezalandırılmaları istenmiştir (No: 1512, 14 Ca 1293/7 Haziran 1876, s. 167). Konuyla ilgili 27 Temmuz 1876'da vilayetten cevap gelmiştir: "İşbu emirnâme-i sâminin vusûlünden bahisle merkûm Mahmûd'un katlinden dolayı taht$\imath$ tevkîf ve istintâka alınan Hasan Kâhya ile Arnavut Rakib'in gerek mahallince ve gerek buraca icrâ kılınan istintâk ve îfâ idilen tahkîkâtda madde-i katlde medhâllerine dâ'ir bir emâre alınamadı̆̆ı gibi

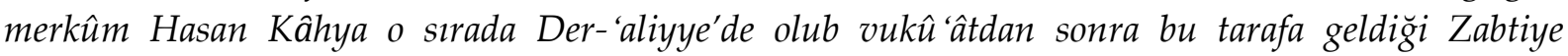
Nezâret-i Celîlesi'nden 7 R 93 târîhli tahrîrâtla mersûl şahâdetnâmede beyân olunmasina mebnî asıl mütecâsirler ele geçirilinceye kadar merkûm Hasan Kâhya'nın muvakkaten sebîli tahliye kılındiğg ve maktûl-ı merkûmun mütecâsirleri zabtiye ma 'rifetiyle taharrî olunmakda bulunduğundan hîn-i derdestlerinde ber-mûceb-i kânûn haklarında lâzım gelen mücâzâtın icrâ kılınacağını mübeyyin 5 Receb 93 târîhli vilâyet-i müşârun-ileyhânın tahrîrât-ı cevâbiyesi kaydı bâlâsına şerh virilmişdir" (No: 74, s. 167).

\section{Af ve Tahliye Talepleri ile Sürgüne Dair Kayıtlar}

Af ve tahliye talepleri hakkında vilayete gönderilen şukkalar da diğerlerinde olduğu gibi sadece dilekçelerdeki ve telgraflardaki beyana veya vilayetten gelen mazbatalara göre yazılmış, olayların araştırılarak gerekli muamelelerin yerine getirilmesi ve sonucun da bildirilmesi istenmiştir. Bu konuya dair yedi adet kayıt tespit edilmiştir. Bunların ikisinde şahısların suçlu olmadıkları, ikisinde şüphe üzerine gözaltına alındıkları iddiaları yer almaktadır. Birisinde ise mahkeme edilmeden uzun süre hapiste tutulan İbrahim ile Arap İsmail'in af edilip serbest bırakılmaları talep edilmektedir. Vilayetten bu kişilerin durumuna dair cevap gelmiş, yapılan mahkeme sonucunda suçlu olduklarının anlaşıldığı Sadaret'e bildirilmiştir. Diğer bir belge ise mahkemesinin yapılarak üç sene kürek cezasına çarptırılan Bekir'in af edilmesi hakkındadır.

Olaya (belgede olayın ne olduğu açıklanmamıştır) dâhil olmadıkları halde üç aydan beri Filibe'de gözaltına alınan Filibeli Bevanço Doşkov ve İstefan Drenski Vranigel isimli kişiler kefaletle serbest bırakılmalarını istemektedirler. Bu konuyla ilgili vilayete gönderilen şukkada benzer durumda olanların affedilmeleri hakkında daha önceden tebliğ edilen hükümlere göre gerekenin yapılması ve bahsedilen şahısların niçin şimdiye kadar tutuklu bulunduklarının açıklanması gerektiği bildirilmiştir (No: 1608, 27 Ş 1293/17 Eylül 1876, s. 197).

Hayrabolu Kazası'ndan Hergelioğlu İbrahim Ağa suçu olmadığı halde Hayrabolu Kazası kaymakamı tarafından hasat esnasında gözaltına aldırıldığını, bundan dolayı zarara uğradığını belirterek gereğinin yapılmasını istemiştir (No: 6877, 27 Ş 1293/17 Eylül 1876, s. 198). Hatice Hatun bir zayiât olayından dolayı şüphe üzerine tutuklanan posta tatarı olan kocasının (No: 2830, 6 Ca 1293/30 Mayıs 1876, s. 164); Asâkir-i şahanenin "tayinât-ı lahmiyesini" üstlenen Kupe isimli tüccar ise yanında çalışan ve şüphe üzerine gözaltına alınan Hıristo'nun istenildiği vakit teslim olması şartıyla serbest bırakılmalarını talep etmişlerdir (No: 3506, 21 Ca 1293/14 Haziran 1876, s. 171). Diğer bir talep de Hasköy'deki malum olaydan (belgede olayın ne olduğu açıklanmamıştır) dolayı üç sene hapsine karar 
verilip Filibe'de tutuklu bulunan Bekir'in af edilmesi için biraderi Mustafa' dan gelmiştir (No: 116, 6 N 1293/25 Eylül 1876, s. 199).

Gelibolu'dan Gülsüm Hatun'un hırsızlık suçlamasıyla iki seneden beri hapiste tutulan kardeşi İbrahim ile Arap İsmail'in serbest bırakılmaların yönündeki talebi ile ilgili vilayete gönderilen şukkada, şahısları yargılamadan uzun süre hapiste tutmanın adalete aykırı olduğu, halk ve muhtarların suçlananların mağdur olduklarını onayladıkları, bu konunun araştırılarak gerçeğin ortaya çıkarılması istenmiştir (No: 3066, 19 Ca 1293/12 Haziran 1876, s. 169). 3 Ağustos 1876 tarihinde bu konuyla ilgili vilayetten gelen cevapta, bahsedilen kişilerin mahkemelerinin yapıldığı, suçlu olduklarının anlaşıldığı ve üçer sene müddetle kürek cezası verildiğine dair mazbatanın Adliye Nezâreti'ne gönderildiği beyan edilmiştir (No: 85, s. 169).

826 nolu Ayniyat defterinin 1876 yılının kayıtlarında sürgün hakkında bir kayıt mevcuttur. Bu kayıt Edirneli Veli Mustafa'nın damadı Ali'nin sürgün kararı ile ilgilidir. Bu hususla ilgili şukkada şöyle yazmaktadır:

"Edirneli Veli Mustafa'nın damadı Mehmed 'Ali nâm şahsın ahvâl ve harekât-ı gayr-ı marziyesinden bahisle münâsib bir mahalle def' ve teb 'îdi için tahte'l-hıfz bâb-ı Zabtiye'ye gönderildiği ifâdesine dâ 'ir vârid olan tahrîrât-ı devletleri me'âli ma 'lûm-ı senâverî oldu. Sûret-i iş 'âra nazaran merkûm sâbıkalı takımından olub habs ve tevkîf olunmuş ise de ıslâh-ı nefs itmeyerek sâ'ir gûne dahi fenâlıkda bulunması melhûz olduğundan kendisinin Diyarbekir'e def've teb '̂̂di Zabtiye Nezâret-i Celîlesi'yle bi'l-muhâbere tensîb olunarak îcâbı icrâ kılınmış olduğu beyânıyla şukka" (No: 128, 25 Receb 1293/16 Ağustos 1876, s. 189).

\section{Sonuç}

Bu çalışmada 826 numaralı Ayniyat defteri verilerine göre Edirne Vilayeti'ndeki 1876 ve öncesinde meydana gelen asayiş problemleri ele alınmıştır.

Defterdeki kayıtlarda arazi ve meralarla ilgili yaşanan ihtilafların cinayet ve hırsızlık gibi diğer vakalara göre çoğunlukta olduğu görülmektedir. Bu türden vakalarda bazen tek bir şahsın, bazen de bütün bir köy halkının şikâyeti söz konusudur. Belgelerdeki verilerde, mağduriyetini bildiren kişi veya kişiler ile karşı taraf arasında mahallinde görülen bir dava kaydı bulunmamaktadır. Bu sebeple bireyler veya bazen de bir köy halkının arazilere ve meralara müdahalelerinin ve başkasının özel mülkünü zorla sahiplenmelerinin bir hak iddiasından mı, kendi arazilerinin verimsizliğinden veya azlığından dolayı geçim sıkıntısı içerisine düştüklerinden mi kaynaklandığı, sadece maddi kazanç elde etmeye mi yönelik olduğu, yoksa başka sebeplerden mi kaynaklandığı yönünde kesin bir kanaat yürütülememektedir. Yaşanan olayların eşkıyalık hareketleriyle bağlantısı olduğu yönünde de bir bulguya rastlanmamış olup, halkın kendi aralarındaki anlaşmazlıklardan kaynaklandığı söylenebilir. Ancak arazi meselelerinin çözümü noktasında Edirne'deki yetkililer tarafından önlem alınmadığı, asayişin sağlanmasında kolluk güçlerinin zaafa düştüğü yine belgelerden anlaşılmakta, bu zaafiyet ve otorite boşluğu yaşanan olayların başlıca sebebi olarak belirgin bir şekilde kendini göstermektedir. Bu durumun ve dönemin siyasi atmosferinin aynı zamanda başkalarının malından ve mülkünden faydalanmaya çalışanların beslendiği kaynak olduğu ifade edilebilir.

Arazi meselelerinde olduğu gibi halk kendilerine zarar verenlerin yakalanmaları ve cezalandırılmaları, mahkeme edilmeden uzun süre hapiste tutulanlar ise tahliye edilmeleri 
için müracaat etmişlerdir. Merkezdeki postanede meydana gelen hırsızlık olayı hakkındaki yazı ise Posta Nezâreti'nin talebi üzerine gönderilmiştir. Bu olaya iki memur dâhil olmuş, buna rağmen vilayet tarafından uzun süre herhangi bir işlem yapılmamıştır. İşlenen diğer suçlar karşısında da vilayette aynı tavrın sergilendiği görülmektedir. Buradan hareketle arazi meseleleri de göz önünde bulundurularak hadiselerin meydana geldiği yerlere bakıldığında kırsal bölgeler ile daha merkezi konumda bulunan bölgelerde asayişin temin edilmesi ve adaletin kısa sürede sağlanması noktasında vilayet idaresinin farklı bir tutum içerisinde olmadığı yine belgelerden anlaşılmaktadır.

Devlet, mevcut olaylar sonucunda ortaya çıan zararların tazmin edilmesi hususunda mahalli idareye görev ve sorumluluklar yüklemiş, öncelikle bir yanlışlı̆̆a meydan verilmemesi için olayların araştırılarak teyit edilmesini de önemle vurgulamıştır. Esasında Ayniyat Defterindeki belgelerden, devletin, içinde bulunduğu kaos ortamına rağmen yapılan bir şikâyet hakkında kayıtsız kalmadığını, meselenin üzerine giderek zaman zaman vilayete de halkın sorunlarını hızlı bir şekilde çözüme kavuşturarak mağduriyetlerin giderilmesi hakkında ihtarlarda bulunduğu anlaşılmaktadır.

826 numaralı defterin sadece bir yıl içerisindeki kayıtlarından yola çıkılarak Edirne Vilayeti'nde meydana gelen asayiş problemlerinin ele alındığı bu çalışmada Ayniyat defterlerinin önemine ayrıca dikkat çekilmek istenmiştir. Sayıları az olsa da diğer yayınlara ve çalışmalara bakıldığında bu defterlerde bulunan belgelerin çok yoğun bir konu çeşitliliğine sahip olduğu açıkça anlaşılmaktadır.

\section{Kaynakça}

\section{Devlet Arşivleri Başkanlığı Osmanlı Arşivi (BOA)}

(Ayniyat Defteri) BOA. BEO. AYN.d. No: 595/826: “Edirne, Adana, Şarkî Rumeli”.

\section{Resmî Yayınlar}

Salname-i Vilayet-i Edirne. 7. Def'a, Edirne Vilayet Matbaası, h.1293 / m. 1876.

Salname-i Vilayet-i Edirne. 8. Def’a, Edirne Vilayet Matbaası, r. 1293 / h. 1294 / m. 1877.

\section{Kitap, Makale, Ansiklopedi Maddeleri ve Tezler}

Aktaş, N. (1991). Ayniyat Defteri. İslam Ansiklopedisi, 4, İstanbul: Türkiye Diyanet Vakfı, 277278.

Aydın, Mahir. (1992). Şarkî Rumeli Vilâyeti. Ankara: Türk Tarih Kurumu.

Aydın, Mithat. (2005). Sir Henry G. Elliot'ın İstanbul Büyükelçiliği (1867-1877) dönemindeki bazı büyük siyasi olaylara bakışı. Ankara Üniversitesi Osmanlı Tarihi Araştırma ve Uygulama Merkezi Dergisi, 18, 21-50.

Başbakanlık Osmanlı Arşivi Rehberi. (2017). İstanbul: Devlet Arşivleri Genel Müdürlüğü Başbakanlık Osmanlı Arşivi Daire Başkanlığı.

Berber, F. (Güz 2011). 19. Yüzyılda Kafkasya'dan Anadolu'ya yapılan göçler. Karadeniz Araştırmaları, 31, 17-49.

Cin, H. (1980). Türk hukukunda mer'a, yaylak ve kışlaklar. Diyarbakır: Dicle Üniversitesi Hukuk Fakültesi Yayını. 
Çadırcı, M. (Aralık 1987). Tanzimat'ın ilânı sıralarında Türkiye'de yönetim (1826-1839). Belleten, LI(201), 1215-1240.

Çeken, Ç. K. (Summer 2018). Osmanlı Devleti'nde 19. yüzyılda mera, yaylak, kışlak, otlak ve çayırların kullanımı ile ilgili yasal düzenlemeler ve ihtilaflarla ilgili örnek kararlar. Turkish Studies, 13(18), 857-872.

Çetin, M. ve Kök, R. (Aralık 2016). Kırım Savaşı, emperyal güçlerin dünya savaşı pratiği. Almatı: Avrupa Araştırma Enstitüsü Yayınevi.

Çetinsaya, G. (2016). II. Abdülhamid'in iç politikası: bir dönemlendirme denemesi. Osmanlı Araştırmaları, 47(47), 353-409.

Devellioğlu, F. (1993). Osmanlıca-Türkçe ansiklopedik lugat. Ankara: Aydın Kitabevi.

Efe, A. (Yaz 2009). Tanzimat'ın eyalet reformları 1840-64 Silistre örneği. Karadeniz Araştırmaları, 6(22), 87-113.

Erdem, U. (2018). Osmanlı'dan Cumhuriyet'e Muhacir Komisyonları ve Faaliyetleri (1860-1923). Ankara: Türk Tarih Kurumu.

Gökmen, E. (Aralık 2018). Ayniyat defterlerinin Osmanlı sosyo-ekonomik tarihi için önemi, bir numaralı Anadolu Adi Ayniyat Defteri örneği. Manisa Celal Bayar Üniversitesi Sosyal Bilimler Dergisi, 16(4), 443-477.

Gökmen, E. ve Özdemir, Ö. Y. (2016). Aydın Vilayeti'nde Suç ve Ceza (1866-1877). İstanbul: Libra Yayıncilik.

Gökmen, E. ve Özdemir, Ö. Y. (2018). Ayniyat Defterleri Işığında Aydın Vilayeti'nin İdari, İktisadi ve Sosyal Durumu (1866-1880). İstanbul: Libra Yayıncllık.

Günay, H. M. (2004). Metrûk, İslam Ansiklopedisi. 29, Ankara: Türkiye Diyanet Vakfı, 416-417.

İpek, N. (1994). Rumeli'den Anadolu'ya Türk göçleri. Ankara: Türk Tarih Kurumu.

Karakuş, S. E. (2018). Osmanlı idaresinde Edirne (1789-1839) (Doktora Tezi, Fırat Üniversitesi, Elazığ). Erişim adresi: http://tez2.yok.gov.tr/

Karal, E. Z. (1988). Osmanlı Tarihi. VII, Ankara: Türk Tarih Kurumu.

Kenanoğlu, M. M. (Bahar 2006). 1858 Arazi Kanunnamesi ve uygulanması. Türk Hukuk Tarihi Araştırmaları, 1, 107-138.

Küçük, C. ve Ertüzün, T. (1994). Düyûn-1 Umumiyye. İslam Ansiklopedisi. 10, Ankara: Türkiye Diyanet Vakf1, 58-62.

Kütükoğlu, M. (2018). Osmanlı belgelerinin dili (diplomatik). Ankara: Türk Tarih Kurumu.

Pakalın, M. Z. (2004). Şukka, Osmanlı tarih deyimleri ve terimleri sözlü̆̆̈̈. I, İstanbul: Milli Eğitim Bakanlığı, s. 360 .

Pamuk, Ş. (2012). Osmanlıdan Cumhuriyete küreselleşme, iktisat politikaları ve büyüme. İstanbul: Türkiye İş Bankası Kültür Yayınları.

Saydam, A. (2016). Muhacir, İslam Ansiklopedisi. Ek-2, İstanbul: Türkiye Diyanet Vakfi, 288290. 
Seyitdanlığlu, M. (Ankara 1996). Tuna Vilâyeti nizâmnamesi. Çă̆daş Yerel Yönetimler, 5(2), 67-81.

Seyitdanlığlu, M. (Eylül 1996). 1871 Vilayet nizamnamesinin getirdikleri. Çă̆daş Yerel Yönetimler, 5(5), 89-103.

Tanzimat sonrası arazi ve tapu. (2014). İstanbul: Osmanlı Arşivi Daire Başkanlığı Yayınları.

Taşkesenlioğlu, M. Y. (Temmuz-Aralık 2015). Kırım ve Kafkasya göçmenlerinin iskânında Meclis-i Tanzimat'ın faaliyetleri. Yeni Türkiye, Kafkaslar Özel Sayısı, IV(74), 554-568. 